Document downloaded from:

http://hdl.handle.net/10251/172315

This paper must be cited as:

Di Fazio, M.; Felici, AC.; Catalli, F.; Domenech Carbo, MT.; De Vito, C.; Doménech-Carbó, A. (2020). Solid-state electrochemical characterization of emissions and authorities producing Roman brass coins. Microchemical Journal. 152:1-9. https://doi.org/10.1016/j.microc.2019.104306

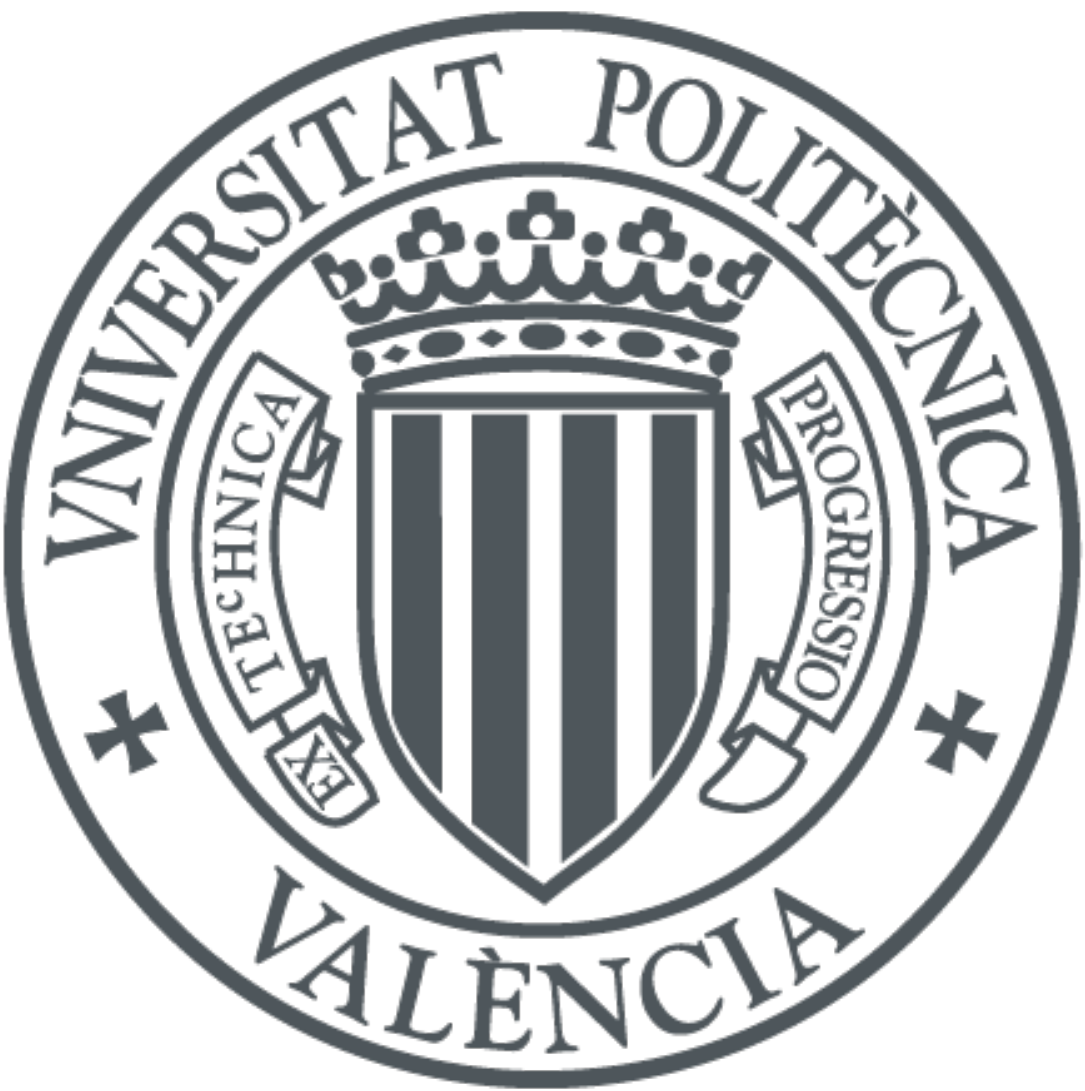

The final publication is available at

https://doi.org/10.1016/j.microc.2019.104306

Copyright Elsevier

Additional Information 


\title{
Solid-state electrochemical characterization of emissions and authorities producing Roman brass coins
}

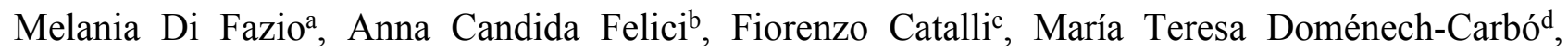
Caterina De Vito ${ }^{\mathrm{a}}$, Antonio Doménech-Carbó*e

a Department of Earth Sciences, Sapienza University of Rome, P.le Aldo Moro 5, Rome, Italy.

${ }^{\mathrm{b}}$ Department of Basic Applied Sciences for Engineering, Sapienza University of Rome, Italy

c Via Attilio Friggeri 95, 00136, Rome, Italy.

d Institut de Restauració del Patrimoni, Universitat Politècnica de València, Camí de Vera 14, 46022, València, Spain.

e Departament de Química Analítica. Universitat de València. Dr. Moliner, 50, 46100 Burjassot (València) Spain.

*Corresponding authors; e-mail: caterina.devito@uniroma1.it; antonio.domenech@uv.es.

\begin{abstract}
The voltammetry of immobilized particles (VIMP) is applied to describe the solid state electrochemistry of brass. This methodology, which involves sampling at the nanogram level, is applied to discriminate mints/authorities producing different Roman monetary emissions covering since the Republic (88 BCE) to Domitianus (55-96 CE) Upon attachment to graphite electrodes in contact with aqueous acetate buffer at $\mathrm{pH} 4.75$, well defined voltammetric responses were obtained centered on $\mathrm{Cu}$ - and $\mathrm{Zn}$-localized signals whose intensity can be correlated to EMP data, being sensitive to the contents of $\mathrm{Zn}(15-30 \% \mathrm{wt})$ and $\mathrm{Sn}(0.01-1.1 \% \mathrm{wt})$. Voltammetric data, combined with ATR-FTIR and FIB-FESEM/EDS, yield information on the structure of the metal patina and permit to characterize different monetary emissions being able, in the case of Augustus' sestertii, to discriminate between the productions from different monetary authorities.
\end{abstract}




\section{Introduction}

Brass is a binary $\mathrm{Cu}-\mathrm{Zn}$ alloy widely used for producing coins since the antiquity [1]. The term Orichalcum is a classical ancient word to describe a Cu-based alloy with discrete percentage of $\mathrm{Zn}$ $(5-28 \% \mathrm{wt})[2,3]$, similar to the modern brass. Higher in value than the bronze, this alloy was melted in the form of ingots [1] and then used to obtain different kinds of objects [4,5]. Orichalcum was rarely exploited to mint coins in the ancient Hellenistic world and, experimentally, was used by Caesar and Marcus Antonius. During the monetary reform of Augustus between 15 BCE and 20-23 $\mathrm{CE}$, there was some uncontrolled emission of sestertii, dupondii and semisses. Orichalcum was regularly used to mint coins, particularly during the monetary reform of Nero (63-65 CE) [6], but this practice decayed at the end of the Iulio-Claudia age. The cementation technique was the usual manufacturing procedure [2,7].

Given the importance of coins as archaeological remains, the characterization of their composition and manufacturing technique are analytical targets of interest usually achieved via chemical and metallographic analysis [8,9] accompanied by electron microscopy, diffraction, different spectroscopic techniques [10-15] and isotope analysis [16]. Direct analysis of the metal requires more or less invasive sampling through cross-sections with the concomitant limitations [17] prompting an increasingly growing interest in techniques that extract archaeometric information from the physico-chemical analysis of the metal patina $[18,19]$.

The corrosion of brass is a complex problem. Under corrosion, brass usually suffers dezincification, a process which is believed to proceed via a) dissolution of both $\mathrm{Cu}$ and $\mathrm{Zn}$ followed by $\mathrm{Cu}$ redeposition, or, b) selective dissolution of $\mathrm{Zn}$ [20]. Interestingly, dezincing reduces the corrosion resistance of brass due to the formation of a copper metal layer but, in the absence of dezincing, the accumulation of copper corrosion products enhances the corrosion through an autocatalytic effect [21]. The presence of low amounts of $\mathrm{Sn}(\mathrm{and} \mathrm{Pb}$ ) prevents to some extent the selective corrosion of zinc, as studied in modern [22,23] and archaeological brasses [24]. Here, the soil-induced corrosion can produce complicated corrosion patterns $[5,25]$.

In this context, the voltammetry of immobilized particles (VIMP), a solid-state electrochemical methodology developed by Scholz et al. [26-28], has been used for the analysis of metals and metal corrosion patinas [29-34], including brass [35]. The inherent high sensitivity of VIMP, needing 
amounts of sample at the nanogram level, has prompted its use in the archaeometric domain [3638], in particular for tracing, mapping and dating metals [39-42].

Studies on metal coins are focused on the determination of the composition and microstructure of the base alloy and the identification of the corrosion products using multi-technique approaches some of which require some destructive sampling [43-45]. In this context, we applied the VIMP methodology in order to acquire archaeometric information based on a minimally invasive (at the nanogram level) sampling on the metal patina. Application to the discrimination of different monetary series was described for silver [46], bronze [47-50] and copper [51] coins, but no studies on orichalcum materials have been done. This is based on the assumption that, under conditions of similar 'corrosion history', subtle differences in the composition and metallographic structure of the coins result in detectable features of the voltammetric response of the corrosion patina. As a result, electrochemical grouping of different sets of coins was obtained without disposal of information on the chemical composition of the metal alloy used in their minting.

The current study was aimed to: i) describe the solid state electrochemistry of orichalcum; ii) establish discrimination criteria for characterizing different monetary emissions made of brass; iii) correlate electrochemical with composition data, and iv) test the possible influence of the degree of corrosion. The question to be elucidated is if it is possible to distinguish different mints and/or authorities producing brass coins from the minimally invasive VIMP sampling. The established electrochemical discrimination criteria have been applied to the study of a set of twenty-five Roman brass coins from private collections, minted between $88 \mathrm{BCE}$ (late Republic) and $96 \mathrm{CE}$ (Domitianus Emperor). They include five denominations (As, Sestertius, Dupondius, Semis and Quadrans) and include five coins without definite ascription, presenting different degree of corrosion, with a non-homogeneous patina. Figure 1 shows the obverse and reverse images of the studied coins.

A sub-set of 11 coins was submitted to partially destructive sampling to determine the composition by EMP analysis in order to gain more information concerning the corrosion process. Such data have been complemented by attenuated total reflectance - Fourier transform infrared spectroscopy (ATR-FTIR) and focusing ion beam-field emission scanning electron microscopy (FIB-FESEMEDS) for the characterization of the corrosion layers of the coins.

\section{Materials and Experimental}


In order to study the structure and elemental composition of the metal patina, FIB-FESEM experiments were carried out with Zeiss (Orsay Physics Kleindiek Oxford Instruments) model Auriga compact equipment. Such experiments permit to perform a square trench of $10 \times 10 \mu \mathrm{m}$ in the coins surface that enabled the characterization of the microtexture and mineral phases in the superficial corrosion layer. For generating the focused beam of $\mathrm{Ga}$ ions the operating conditions were voltage, $30 \mathrm{kV}$ and current intensity, $500 \mu \mathrm{A}$ and $20 \mathrm{nA}$ in the FIB. A voltage of $3 \mathrm{kV}$ was used in the FESEM for photographs. X-ray linescans were performed in the trench operating with an Oxford-X Max X-ray microanalysis system coupled to the FESEM controlled by Aztec software. A voltage of $20 \mathrm{kV}$ and a working distance of $6-7 \mathrm{~mm}$ was used. SEM investigation on cross sections from the corroded rim to the un-corroded core was performed using a FEI-Quanta 400 (SEM-EDS) instrument, operating at $30 \mathrm{kV}$, equipped with X-ray energy-dispersive spectroscopy (Department of Earth Sciences, Sapienza University of Rome, Italy).

To determine the composition of the metal core of 11 of the studied coins, EMP for quantitative chemical analyses were performed using a Cameca SX50 electron microprobe equipped with five wavelength-dispersive spectrometers (CNR-IGAG, Rome, c/o Department of Earth Sciences, Sapienza University of Rome). The operating conditions were: accelerating voltage $15 \mathrm{kV}$, beam current $15 \mathrm{nA}$. Element peaks and background were measured with counting times of 20 and $10 \mathrm{~s}$ respectively. Metallic $\mathrm{Cu}$ and metallic $\mathrm{Zn}$ were used respectively as a reference standard for $\mathrm{Cu}$ and 
$\mathrm{Zn}$ (LIF), galena for Pb (PET), cassiterite for Sn (PET), metallic Ni and metallic co respectively for $\mathrm{Ni}$ and Co (LIF), synthetic GaAs for As (TAP), rhodonite and metallic Mn for Mn (PET), olivine and synthetic magnetite for Fe (LIF). Matrix corrections were calculated by the PAP method [52], with software supplied by Microbeams Services. The detection limits under the specified work conditions vary from 0.05 to $0.1 \mathrm{wt} \%$ with standard deviations from 0.02 to $0.04 \mathrm{wt} \%$. The analytical error was $\approx 1 \%$ rel. for the major elements, and it increases as the concentration decreases up to $10 \%$ for trace elements.

Voltammetry of Microparticles were performed at $298 \mathrm{~K}$ in a three-electrode cell using a CH I660C device (Cambria Scientific, Llwynhendy, Llanelli UK) using air-saturated aqueous $0.25 \mathrm{M}$ $\mathrm{HAc} / \mathrm{NaAc}$ aqueous buffer solution (Panreac) at $\mathrm{pH}$ 4.75. A sample-modified graphite bar (Alpino, HB type, $3 \mathrm{~mm}$ diameter) was used as a working electrode, the three-electrode arrangement being completed by a platinum wire auxiliary electrode and an $\mathrm{Ag} / \mathrm{AgCl}(3 \mathrm{M} \mathrm{NaCl})$ reference electrode. The analysis of coins was carried out by pressing a graphite bar onto selected spots of the coin surface (regions where no pit corrosion of green products exists) as already described [46-51]. Depending on the number and extension of such spots 3-5 replicate measurements were performed on each coin. Square wave voltammetry (SWV) was used as a detection mode determining successively the negative- and the positive-going potential scans using as parameters: potential step increment $4 \mathrm{mV}$; square wave amplitude $25 \mathrm{mV}$; frequency $5 \mathrm{~Hz}$.

\section{Results and Discussion}

\subsection{Composition of patina and corrosion products}

The study involves balancing the information on the chemical composition of the coin's patina, to be acquired from ATR-FTIR spectra, the elemental composition of the base alloy provided by EMP analysis and the structure and composition of the subsurface corrosion layers from FIB-FESEM in order to combine it with VIMP analysis.

The ATR-FTIR measurements were acquired on the patinas of a limited number of coins (i.e., A1, A2, A3, A9, 1, 2, 5, 10, B4, B15, C9, E5, E6, 213, 226, 232), due to the low quantity of collectable material. Figure 2 shows the IR absorption spectra of samples 1, 10, 213 and 232, representative of the entire set of the coins. Some spectra revealed the presence of atacamite/clinoatacamite $\left(\mathrm{Cu}_{2}(\mathrm{OH})_{3} \mathrm{Cl}\right)$ in the patina (bands at 3436, 3330, 3310, 890, 840, 949 and $985 \mathrm{~cm}^{-1}$ in Figure 2a and 2d) and malachite $\mathrm{Cu}\left(\mathrm{CO}_{3}\right) \cdot \mathrm{Cu}(\mathrm{OH})_{2}$ (bands at 3400, 3309, 1486, 1395, 1039, 864, 743 and 
$703 \mathrm{~cm}^{-1}$ in Fig 2a-c). Furthermore, specific absorption bands can be assigned to different components of the patina. The band at $\sim 3571 \mathrm{~cm}^{-1}$ in sample 1 (Figure 2a) can indicate the presence of clay materials in the patina, probably as a burial contaminant. The presence of a band at 1584 $\mathrm{cm}^{-1}$ can be attributed to the presence of copper carboxylates. Other possibility is the presence of copper(II) acetate resulting of the corrosion process due to old cleaning treatments, but the presence in the spectra of bands of organic compounds resulting from the contact with the human skin oils and their alteration products of oxalate type (vide infra), denotes the significant maintenance of the original coin surface

Bands at $\sim 2962 \mathrm{~cm}^{-1}, \sim 2923 \mathrm{~cm}^{-1}, \sim 2852 \mathrm{~cm}^{-1}$ and $\sim 2807 \mathrm{~cm}^{-1}$ for the sample 1 (Figure 2a), 2924 $\mathrm{cm}^{-1}$ and $\sim 2855 \mathrm{~cm}^{-1}$ for the sample 10 (Figure $2 \mathrm{~b}$ ), $\sim 2916 \mathrm{~cm}^{-1}$ and $\sim 2848 \mathrm{~cm}^{-1}$ for the sample 232 can represent the organic compounds of the patina. The band at $\sim 1738 \mathrm{~cm}^{-1}$ for the sample 10 , well visible in Figure $2 b$, can be assigned to the stretching vibrations of $\mathrm{C}=\mathrm{O}$ group, that indicate the presence of lipids. The occurrence of lipids in the corrosion layer is the result of the contact of the coin with the human skin oils, present on the hands of the ancient users of these coins when were in circulation [50]. Moreover, the presence of bands at 1584 and $1541 \mathrm{~cm}^{-1}$ (Figure 2c), typical of the copper and zinc stearates or zinc palmitates, is an evidence of the reactions of free fatty acids hydrolysed from lipids with $\mathrm{Cu}(\mathrm{II})$ and $\mathrm{Zn}$ (II) metal ions released from the coin during corrosion processes. Finally, the bands at $\sim 1376$ and $1364 \mathrm{~cm}^{-1}$ (Figure 2a and 2c) and at $\sim 1319 \mathrm{~cm}^{-1}$ (Figure 2c) can be assigned to the copper and calcium oxalates, respectively. These compounds are the result of the degradation of lipids to oxalates and further complexation with metal ions $[43,50]$.

A group of selected samples (i.e., 2, 236, B14, B15, E5) were analysed using FIB-FESEM, a nanoinvasive technique, aiming to investigate the corrosion pattern occurring in the first $\sim 10 \mu \mathrm{m}$ in depth of the patina. Figure 3 shows secondary electron images of the trenches obtained with the Ga ion beam for two representative coins, illustrating different corrosion patterns and semi-quantitative elemental composition of the patina. Coin 236 (Figure 3a,c) presents a high degree of corrosion in the external layer. Indeed, the first $3 \mu \mathrm{m}$ of the patina are characterized by micro-domains with low amount of $\mathrm{Zn}$, due to a selective de-alloying.

The more porous external layer of coin B14 (Figure 3b,d) extends up to $4 \mu \mathrm{m}$ in deep, due to the dezincification process in the $\mathrm{Zn}$-rich micro-domains of the alloy. The segregation areas of $\mathrm{Cu}$ and $\mathrm{Zn}$ are well visible in the deeper region of the analysed patina. Moreover, all the samples present small pores and cracks lines, due both to mechanical stress and corrosion process. The patterns are 
comparable to the one previously described [44], especially for the samples 2, 236, B15 and E5 that cannot be analysed using destructive techniques, e.g. EMP analysis on cross sections.

EMP analysis (Table 2) were acquired in the un-corroded metallic nucleus of a sub-set of 11 sacrificed coins, i,e., sectioned as already reported [44]. The content of $\mathrm{Zn}$ ranges between $15 \%$ and $30 \%$ with the concomitant variation in the percentage of $\mathrm{Cu}$, as can be seen in Figure 4 . It is possible to notice a regular variation between the two main component of the alloy, considering their average values in the un-corroded core of each sample. Nevertheless, taking into account different periods of minting, $\mathrm{Zn}$ and $\mathrm{Cu}$ contents in the alloy have an irregular fluctuation of values, making impossible a grouping of samples. In contrast, the representation of the Sn content vs. the $\mathrm{Zn}$ content (inset in Figure 4), permits to separate the coins in three groups. The first one includes coins A2, 5, B4, 10, A, B14, and 20, having Sn content below 0.15\%; B5 coin has $0.25 \%$ of Sn and coins A1, A3, A9 with content of Sn ranging from 0.7 to $1.1 \%$.

\subsection{Voltammetric pattern}

The voltammetric response of coin samples on graphite electrodes was recorded in contact with airsaturated aqueous $0.25 \mathrm{M} \mathrm{HAc} / \mathrm{NaAc}$ aqueous buffer solution at $\mathrm{pH}$ 4.75. Three replicates were performed for each coin sampling in three different areas of the same. Figure 4 illustrates the typical negative- and positive-going potential scan voltammograms for a,b) coin 1, a Caesar's $A s$ produced in 44 BCE and c,d) coin B15, a Tiberius' Sestertius minted in 22-23 CE. In the initial negativegoing potential scan (Figures 4a,c), cathodic peaks at ca. 0.0 and $-0.60 \mathrm{~V}$ vs. $\mathrm{Ag} / \mathrm{AgCl}$ appear, followed by a prominent rising current at ca. $-1.0 \mathrm{~V}$. This last can be attributed to the hydrogen evolution reaction (HER) whereas the signal at $0.0 \mathrm{~V}(\mathrm{C} 1)$ can be assigned to the reduction of cuprite and other corrosion products (malachite-, brochantite-, atacamite-type minerals) to copper metal. The reduction of tenorite $(\mathrm{CuO})$ occurs between -0.4 and $-0.5 \mathrm{~V}$ [46-51], here appearing as an ill-defined shoulder (C2). The cathodic wave at $-0.60 \mathrm{~V}(\mathrm{C} 3)$ can be mainly attributed to the reduction of dissolved oxygen (oxygen reduction reaction, ORR) but it is more or less peaked due to the superposition of the reduction of lead corrosion products [53,54]. In turn, the reduction of zinc corrosion products will occur at more negative potentials, being indistinguishable from the HER process under our experimental conditions.

In the positive-going potential scan voltammograms (Figure $4 \mathrm{~b}, \mathrm{~d}$ ) anodic signals appear between 0.0 and $+0.20 \mathrm{~V}$ (A1) and at ca. $-0.80 \mathrm{~V}$ (A2). These signals can in principle be attributed to the oxidative dissolution (anodic stripping) of the metal deposits ( $\mathrm{Cu}$ and $\mathrm{Zn}$, respectively) formed at 
negative potentials as a result of the reduction of corrosion products. Minor signals at ca. $-0.60 \mathrm{~V}$ can be assigned to the presence of $\mathrm{Pb}$ (and $\mathrm{Sn}$ ) corrosion products $[53,54]$.

Interestingly, replicate measurements in different spots of the same coin produced quite similar voltammetric profiles. Given the relatively large area of sampling (ca. $7 \mathrm{~mm}^{2}$ ), the sampling compensate the local differences in roughness (surface features below the $\mu \mathrm{m}$ level, see Figure 2) between different regions of the same coin and between different coins. The relevant point to emphasize is that the relative height of the different voltammetric signals exhibits small but significant variations from one sample to another. This can be seen on comparing the series of replicate voltammograms for coins A9 (As, Claudius, 10-54 CE) and 213 (Sestertius, Augustus, 16 BCE) presented as a Supplementary Information (Figures S.1 and S.2). Although displaying common general profiles, the ratio between the intensities of different pairs of signals exhibit significant variations.

The above differences result from i) differences in the composition and metallographic treatment of the base metal alloy and ii) differences in the 'corrosion history' of the coin. Assuming that, sampling in regions of moderate corrosion of the coins, there is possibility of assuming reasonably uniform conditions of corrosion, we can attempt to group the coins on the basis of the variation of selected pairs of currents.

\subsection{VIMP grouping}

For grouping purposes, the intensities of the different voltammetric peaks can be used [46-50]. As a preliminary requirement for grouping purposes, the self-consistency of voltammetric data has to be tested. Figure 5 depicts the representation of the peak current for the signals A1 and A2, i(A1), $i(\mathrm{~A} 2)$, vs. the peak current for the process $\mathrm{C} 1, i(\mathrm{C} 1)$, for coin samples in this study (3 replicate measurements are presented as separate data points for each sample) using peak current measured in square wave voltammograms such as in Figure 4. Since, as previously described, the signals $\mathrm{C} 1$ and A1 (sum of the two resolved peaks) correspond to copper-centered signals recorded for the same sample, their peak currents should be proportional. Consistently, the plot of $i(\mathrm{~A} 1)$ vs. $i(\mathrm{C} 1)$, although with some data dispersion, defines a straight line passing by the origin. In contrast, the plot of of $i(\mathrm{~A} 2)$ vs. $i(\mathrm{C} 1)$ does not show a comparable variation. Here, the values of the signal A2, attributed previously to the stripping of $\mathrm{Zn}$, appear as independent on the copper-localized signal C1. 
In principle, the voltammetric response appears to be directly related to the composition of the base metal. Figure 6 a depicts the plots of $i(\mathrm{~A} 2)$ vs. $i(\mathrm{~A} 1)$ for samples $\mathrm{A} 9$, 5, and 10, corresponding, respectively, to a Claudius' as, a Tiberius' Sestertius, and a Claudius' Sestertius. The data points for five replicate experiments on each coin fall in a common tendency curve so that the values of $i$ (A2) relative to those of $i(\mathrm{~A} 1)$ increase on increasing the $\mathrm{Zn}$ content on the base metal determined from EMP analysis (EMPA) of coins cross sections (30.6, 23.3, $18.8 \% \mathrm{wt}$, respectively). This result can be rationalized on considering that, even after dezincification, the composition of the corrosion layer of the coins should be representative of the composition of the base metal alloy so that the stripping peaks for zinc and copper will reflect the relative abundances of such metals in the coin core.

There is, however, a more complicated situation because the proportion of $\mathrm{Sn}$ also plays a significant role in the electrochemical response. This can be seen in Figure 6b, where the $i$ (A2) vs. $i$ (A1) plots for samples A9 and B5, this last a Claudius' as, both containing a 30\% wt Zn but clearly different Sn contents (1.08 and $0.25 \% \mathrm{wt})$, can be compared. One can see in this figure that the curve for the coin containing the highest $\mathrm{Sn}$ content reinforces the overall $i(\mathrm{~A} 2) / i(\mathrm{~A} 1)$ ratio relative to the other. This is, in principle, consistent with the inhibiting effect exerted by tin on dezincification of brass [24]: the coin containing the higher Sn content presents a corrosion layer enriched in $\mathrm{Zn}$. Data in Figure 6 consistent with the foregoing set of considerations taking into account that the percentage of $\mathrm{Zn}$ of the coins $\mathrm{A} 1$ and $\mathrm{A} 2$ is similar $(21.30$ and $28.03 \% \mathrm{wt}$, respectively), but their Sn content is clearly different ( $0.73 \%$ wt for A1 and $0.06 \%$ wt for A2).

The same representation of the $\ln (i(\mathrm{~A} 2))$ vs. $\ln (i(\mathrm{~A} 1))$ for Augustus' Sestertii reveals systematic differences depending on the emission authority. As can be seen in Figure 7, coins from Asinio Gallo $(235,236)$ and Plotius Rufus $(226,232,240)$, define two tendency lines which differs from the line defined by Sestertii from Casius Celler (A3), Gallius Lupercus (213, 228), Gnaeus Calpurnius Piso (234), and Naevius Surdinus (227) corresponding, apparently, to lower Zn and/or Sn contents.

In the series of Augustus' Sestertii there is only disposal of composition data for sample A3, characterized by a low zinc content $(17.32 \% \mathrm{wt})$ and a high tin content $(0.72 \% \mathrm{wt})$. Accordingly, and taking into account the previously described results, it appears reasonable to attribute the Augustus' Sestertii minted under the authority of Asinio Gallo and Plotius Rufus to a production with relatively high $\mathrm{Zn}$ and/or Sn contents whereas the production under the authority of Naevius 
Surdinus, and Gnaeus Calpurnius Piso, Cassius Celler and Gallius Lupercus, would be characterized by lower $\mathrm{Zn}$ and/or Sn contents. Conjointly considered these results illustrate the capability of VIMP measurements to discriminate between monetary emissions.

Although studies on copper coins are focused on elemental analysis and microstructure [1-3,4345,55-58], prompting the characterization of provenances and ateliers preparing forgeries [58]. Recently, Caponetti et al. concluded that $\mathrm{Cd}, \mathrm{Ag}, \mathrm{Zn}, \mathrm{Bi}, \mathrm{As}$, ans $\mathrm{Sn}$ are the elements with more discriminant capacity in regard to grouping orichalcum ingots from the underwater Gela's archaeological site [1], whereas Griesser et al. [55] have underlined the importance of the casting technique in the corrosion of leaded copper coins. Conjointly considered, these results can be seen as consistent with the electrochemical data presented here underlining the importance of the composition, but also of variations in the minting technique, in the composition and structure of the metal patina and hence on the voltammetric response which in turn constitutes the basis for the electrochemical grouping described here for orichalcum coins.

\section{Conclusions}

All coins displayed a relatively similar corrosion pattern, with prevalence of copper corrosion products and more or less extensive dezincification, as denoted by FIB-FESEM/EDS data. Indeed, FESEM analysis shows a high degree corroded patina, characterized by micro-domains with low amount of $\mathrm{Zn}$ and a porous structure due to the progressive de-alloying process. To have a multianalytic point of view, a low amount of patina from selected coins was analysed by ATR-FTIR. Data acquired confirm the prevalence of copper corrosion products compared to zinc products, confirming the dezincification of the external layers of the samples.

The voltammetric response of submicro-samples from the patina of a series of orichalcum Roman coins covering from the late Republic to Domitianus in contact with aqueous acetate buffer at $\mathrm{pH}$ 4.75 provides distinctive signals for copper corrosion products accompanied by anodic signals corresponding to the stripping of copper and zinc. The intensity of the later signals can be correlated to the averaged elemental compositions of the metallic nucleus known for a sub-set of the studied coins.

Quantitative data obtained by EMP analysis allow to evaluate the real composition of the alloy in the un-altered core of sample. Here, the ratio $\mathrm{Zn} / \mathrm{Cu}$ was found to be sensitive to the $\mathrm{Zn}$ content 
(between 15 and $30 \% \mathrm{wt}$ ) but also to the Sn content (between 0.01 and $1.08 \% \mathrm{wt}$ ). Replicate voltammetric measurements on different points of the studied coins permits to obtain tendency curves which permit the grouping of coins by emissions and, in the case of Augustus' Sestertius, even discriminate between coins emitted under different authorities.

Acknowledgments: Financial support is gratefully acknowledged from the Spanish " $\mathrm{R}+\mathrm{D}+\mathrm{I}$ " project CTQ2017-85317-C2-1-P, CTQ2014-53736-C3-1-P and CTQ2014-53736-C3-2-P, which are supported by the Ministerio de Ciencia, Innovación y Universidades, Fondo Europeo de Desarrollo Regional (ERDF) funds and Agencia Estatal de Investigación (AEI). The authors wish to thank Mr. Manuel Planes, Dr. José Luis Moya and Mrs. Alicia Nuez Inbernón, technical supervisors of the Electron Microscopy Service of the Universitat Politècnica de València. 


\section{References}

[1] E. Caponetti, F. Armetta, L. Brusca, D.C. Martino, M.L. Saladino, S. Ridolfi, G. Chirco, M. Berrettoni, P. Conti, N. Bruno, S. Tusa, A multivariate approach to the study of orichalcum ingots from the underwater Gela's archaeological site, Microcehm. J. 135 (2017) 163-170.

[2] P.T. Craddock, The composition of the copper alloys used by the Greek, Etruscan and Roman civilizations, J. Archaeol. Sci. 5 (1978) 1-16.

[3] T. Rehren, Small Size, Large Scale Roman Brass Production in Germania Inferior, J. Archaeol. Sci. 26 (1999) 1083-1087.

[4] C. Martini, C. Chiavari, F. Ospitali, F. Grazzi, A. Scherillo, C. Soffritti, G.L. Garagnani, Investigations on a brass armour: Authentic or forgery?, Mater. Chem. Phys. 142 (2013) 229-237.

[5] M.I. Barrena, J.M. Gómez de Salazar, A. Soria, Corrosion of brass archaeological blinker: Characterisation of natural degradation process, Mater. Lett. 62 (2008) 3944-3946.

[6] F. Catalli, Numismatica greca e romana, Istituto Poligrafico e Zecca dello Stato, Roma, 2003.

[7] D. Bourgarit, F. Bauchau, The ancient brass cementation processes revisited by extensive experimental simulation, JOM. 62 (2010) 27-33.

[8] D.A. Scott, Metallography and Microstructure of Ancient and Historic Metals, The Getty Conservation Institute, Paul Getty Museum, Malibu, 1991.

[9] I. Constantinides, A. Adriaens, F. Adams, Surface characterization of artificial corrosion layers on copper alloy reference materials. Appl. Surf. Sci. 189 (2002) 90-101.

[10] J. Peris-Vicente, F.M. Valle-Algarra, M.A. Ferrer-Eres, J.V. Gimeno-Adelantado, R. MateoCastro, M.D. Soriano-Piñol, Archaeometrical study of paleometallurgical materials from the archaeological site "Cerro de las Balsas - Chinchorro" (La Albufereta, Alacant, Spain), Microchem. J. 90 (2008) 142-146.

[11] M.A. Ferrer-Eres, J. Peris-Vicente, F.M. Valle-Algarra, J.V. Gimeno-Adelantado, S. SánchezRamos, M.D. Soriano-Piñol, Archaeopolymetallurgical study of materials from an Iberian culture site in Spain by scanning electron microscopy with X-ray microanalysis, chemometrics and image analysis, Microchem. J. 95 (2010) 298-305.

[12] J.M. del Hoyo-Meléndez, P. Swit, M. Matosz, M. Wozniak, A. Klisinska-Topacz, L. Bratasz, micro-XRD analysis of silver coins from mediaeval Poland, Nucl. Inst. Meth. Phys. Res. B 349 (2015) 6-16.

[13] M. Carl, M.L. Young, Complementary analytical methods for analysis of Ag-plated cultural heritage objects, Microchem. J. 126 (2016) 307-315.

[14] L. Lutterotti, F. Dell'Amore, D.E. Angelucci, F. Carrer, S. Gialanella, Combined X-ray diffraction and fluorescence analysis in the cultural heritage field, Microchem. J. 126 (2016) 423430 . 
[15] J. Agresti, I. Osticioli, M.C. Guidotti, N. Kardjilov, S. Siano, Non-invasive archaeometallurgical approach to the investigations of bronze figurines using neutron, laser, and $\mathrm{X}$ ray techniques, Microchem. J. 124 (2016) 765-774.

[16] S.S. Gomes, A. Monge Soares, M.F. Araujo, V.H. Correia, Lead isotopes and elemental composition of Roman fistulae plumbeae aquariae from Conimbriga (Portugal) using Quadrupole ICP-MS, Microchem. J. 129 (2016)184-193.

[17] D.A. Scott, An examination of the patina and corrosion morphology of some Roman bronzes, J. Am. Ite. Cons. 33 (1994) 1-23.

[18] L. Robbiola, R. Portier, A global approach to the authentication of ancient bronzes based on the characterization of the alloy-patina-environment system, J. Cult. Herit. 7 (2006) 1-12.

[19] L. Robbiola, J. -M. Blengino, C. Fiaud, Morphology and mechanisms of formation of natural patinas on archaeological CuSn alloys, Corros. Sci. 40 (1998) 2083-2111.

[20] E. Mattsson, Corrosion of Copper and Brass: Practical Experience in relation to Basic Data. Br. Corros. J. 15 (1980) 6-13.

[21] I.K. Marshakov, Corrosion resistance of Dezincing of Brasses, Protect. Met. 41 (2005) 205-210. (Translated from Zashchita Metallov, 41 (2005) 227-233).

[22] S. Sohn, T. Kang, The effects of tin and nickel on the corrosion behavior of 60Cu-40Zn alloys, J. Alloys Comp. 335 (2002) 281-289.

[23] R. Karpagavalli, R. Balasubramaniam, Development of novel brasses to resist dezincification. Corr. Sci. 9 (2007) 963-979.

[24] L. Campanella, O. Colacicchi Alessandri, M. Ferretti, S.H. Plattner, The effect of tin on dezincification of archaeological copper alloys, Corros. Sci. 51 (2009) 2183-2191.

[25] O. Papadopoulou, P. Vassiliou, S. Grassini, E. Angelini, V. Gouda, Soil-induced corrosion of ancient Roman brass - A case study. Mater. Corros. 67 (2016) 160-168.

[26] F. Scholz, B. Meyer, Voltammetry of solid microparticles immobilized on electrode surfaces, Electroanalytical Chemistry, A Series of Advances, Bard, A. J., and Rubinstein, I., Eds., Marcel Dekker, New York, 1998, vol. 20, pp. 1-86.

[27] F. Scholz, U. Schröder, R. Gulabowski, A. Doménech-Carbó, Electrochemistry of Immobilized Particles and Droplets, 2nd edit. Springer, Berlin-Heidelberg, 2014.

[28] A. Doménech-Carbó, J. Labuda, F. Scholz, Electroanalytical chemistry for the analysis of solids: characterization and classification (IUPAC Technical Report), Pure Appl. Chem. 85 (2013) 609-631.

[29] A. Doménech-Carbó, M. T. Doménech-Carbó, I. Martínez-Lázaro, Electrochemical identification of bronze corrosion products in archaeological artefacts. A case study, Microchim. Acta 162 (2008) 351-359. 
[30] V. Costa, K. Leyssens, A. Adriaens, N. Richard, F. Scholz, Electrochemistry reveals archaeological materials, J. Solid State Electrochem. 14 (2010) 449-451.

[31] F. Arjmand, A. Adriaens, Electrochemical quantification of copper-based alloys using voltammetry of microparticles: optimization of the experimental conditions, J. Solid State Electrochem. 16 (2012) 535-543.

[32] M. Serghini-Idrissi, M. C. Bernard, F. Z. Harrif, S. Joiret, K. Rahmouni, A. Srhiri, H. Takenouti, V. Vivier, M. Ziani, Electrochemical and spectroscopic characterizations of patinas formed on an archaeological bronze coin, Electrochim. Acta 50 (2005) 4699-4709.

[33] D. Satovic, S. Martinez, A. Bobrowski, Electrochemical identification of corrosion products on historical and archaeological bronzes using the voltammetry of micro-particles attached to a carbon paste electrode, Talanta 81 (2010) 1760-1765.

[34] A. Doménech-Carbó, M. Lastras, F. Rodríguez, L. Osete-Cortina, Mapping of Corrosion Products of Highly Altered Archaeological Iron Using Voltammetry of Microparticles. Microchem. J. 106 (2013) 41-50.

[35] G. Cepriá, C. Aranda, J. Pérez-Arantegui, F. Lacueva, J.R. Castillo, Voltmmetry of immobilised microparticles: a powerful analytical technique to study the physical and chemical composition of brass, J. Electroanal. Chem. 513 (2001) 52-58.

[36] A. Doménech-Carbó, M. T. Doménech-Carbó, V. Costa, Electrochemical Methods in Archaeometry, Conservation and Restoration. Monographs in Electrochemistry Series, Scholz, F., Ed. Springer, Berlin-Heidelberg, 2009.

[37] A. Doménech-Carbó, Voltammetric methods applied to identification, speciation and quantification of analytes from works of art: an overview. J. Solid State Electrochem. 14 (2010) 363-369.

[38] A. Doménech-Carbó, M.T. Doménech-Carbó, Electroanalytical techniques in archaeological and art conservation, Pure Appl. Chem. 90 (2018) 447-462.

[39] A. Doménech-Carbó, Electrochemical dating: a review, J. Solid State Electrochem. 21 (2017) 1987-1998.

[40] A. Doménech-Carbó, F. Scholz, Electrochemical age determinations of metallic specimens - the utilization of the corrosion clock, Acc. Chem. Res. 52 (2019) 400-406.

[41] A. Doménech-Carbó, M.T. Doménech-Carbó, M.A. Peiró-Ronda, Dating archaeological lead artifacts from measurement of the corrosion content using the voltammetry of microparticles, Anal. Chem. 83 (2011) 5639-5644.

[42] A. Doménech-Carbó, M.T. Doménech-Carbó, S. Capelo, T. Pasíes-Oviedo, I. Martínez-Lázaro, Dating archaeological copper/bronze artifacts using the voltammetry of microparticles, Angew. Chem. Int. Ed. 53 (2014) 9262-9266.

[43] A. Inberg, D. Ashkenazi, M. Cohen, N. Iddan, D. Cvikel, Corrosion products and 
microstructure of copper alloy coins from the Byzantine-period Ma'agan Mikhael B shipwreck, Israel. Microchem. J. 143 (2018) 400-409

[44] M. Di Fazio, A.C. Felici, F. Catalli, C. De Vito, Microstructure and chemical composition of Roman orichalcum coins emitted after the monetary reform of Augustus (23 B.C.), Sci. Reports 9 (2019) 12668.

[45] M.T. Doménech-Carbó, C. Álvarez-Romero, A. Doménech-Carbó, L. Osete-Cortina, M. L. Martínez-Bazán, Microchemical surface analysis of historic copper-based coins by the combined use of FIB-FESEM-EDX, OM, FTIR spectroscopy and solid-state electrochemical techniques, Microchem. J. 148 (2019) 573-581.

[46] A. Doménech-Carbó, J. Del Hoyo-Menéndez, M.T. Doménech-Carbó, J. Piquero-Cilla, Electrochemical analysis of the first Polish coins using the voltammetry of immobilized particles, Microchem. J. 130 (2017) 47-55.

[47] F. Di Turo, N. Montoya, J. Piquero-Cilla, C. De Vito, F. Coletti, G. Favero, A. DoménechCarbó, Archaeometric analysis of Roman bronze coins from the Magna Mater temple using solidstate voltammetry and electrochemical impedance spectroscopy, Anal. Chim. Acta 955 (2017) $36-47$.

[48] A. Doménech-Carbó, M.T. Doménech-Carbó, C. Álvarez-Romero, N. Montoya, T. PasíesOviedo, M. Buendía, Electrochemical characterization of coinage techniques the 17th century: The maravedís case, Electroanalysis 29 (2017) 2008-2018.

[49] F. Di Turo, N. Montoya, J. Piquero-Cilla, C. De Vito, F. Coletti, G. Favero, M.T. DoménechCarbó, A. Doménech-Carbó, Dating Archaeological Strata in the Magna Mater Temple Using Solid-state Voltammetric Analysis of Leaded Bronze Coins, Electroanalysis 30 (2018) 361-370.

[50] A. Doménech-Carbó, M.T. Doménech-Carbó, C. Álvarez-Romero, T. Pasíes-Oviedo, M. Buendia, Screening of Iberian coinage in the $2^{\text {th }}-1^{\text {th }}$ BCE period using the voltammetry of immobilized particles, Electroanalysis 31 (2019) 1164-1173.

[51] A. Doménech-Carbó, M.T. Doménech-Carbó, E. Montagna, C. Álvarez-Romero, Y. Lee, Electrochemical discrimination of mints: the last Chinese emperors Kuang Hsü and Hsüan T'ung monetary unification, Talanta 169 (2017) 50-56.

[52] J. Pouchou, F. Pichior, "PAP" $\mathrm{f}(\mathrm{rZ})$ procedure for improved quantitative analysis, in: Microbeam Analysis, San Francisco Press, J.T. Armstrong, Ed., San Francisco, 1985: pp. 104-106.

[53] A. Doménech-Carbó, M.T. Doménech-Carbó, J. Redondo-Marugán, L. Osete-Cortina, M.V. Vivancos-Ramón, Electrochemical characterization of corrosion products in leaded bronze sculptures considering ohmic drop effects on Tafel analysis, Electroanalysis, 28 (2016) 833-845.

[54] A. Doménech-Carbó, M.T. Doménech-Carbó, J. Redondo-Marugán, L. Osete-Cortina, J. barrio, A. Fuentes, M.V. Vivancos-Ramón, W. Al-Sekkaneh, B. Martínez, I. Martínez-Lázaro, T. PasíesOviedo, Electrochemical characterization and dating of archeological leaded bronze objects using the voltammetry of immobilized particles, Archaeometry 60 (2018) 308-324. 
[55] M. Griesser, W. Kockelmann, K. Hradil, R. Traum, New insights into the manufacturing technique and corrosion of high leaded antique bronze coins. Microchem. J. 126 (2016) 181-193.

[56] K.K.A. Lönnkvist, A second investigation into the chemical composition of the Roman provincial (procuratorial) coinage of Judea, AD 6-66. Archaeometry 48 (2003) 45-60.

[57] S. Klein, Y. Lahaye, G.P. Brey, The early Roman inmerial aes coinage II: tracing the copper sources by analysis of lead and copper isotopes -copper coins of Augustus and Tiberius. Archaeometry 46 (2004) 469-480.

[58] A. Deraisme, J.-N. Barrandon, Unofficial coinage in the thirs century AD in the Gallo-Roman world: chemical and physical analyses for determining the location of the workshop. Archaeometry 50 (2008) 835-854. 
Figures

Figure 1. The orichalcum coins studied in this work. For samples A1, A2, A3, B4, B5, B14, C9, 5, 10, and 20 see Di Fazio et al. [44]. Numismatic and historic information is reported in Table 1.

Figure 2. ATR-FTIR Spectra of sample1 1 (a), 10 (b), 213 (c), 232 (d) compared with the spectra of reference materials.

Figure 3. Secondary electron images acquired at $3 \mathrm{kV}$ of the trenches on coins 236 (a,c) and B14 (b,d). Representative X-ray microanalysis carried out in points A (Fig. 3a) and B (Fig. 3b) are reported. Trench image width $15 \mu \mathrm{m}$, trench image depth $10 \mu \mathrm{m}$. Spectrum A (Fig 3c): $75.5 \mathrm{wt} \%$ $\mathrm{Cu}$ and $5.5 \mathrm{wt} \%$ content ; spectrum B (Fig 3d): $76.3 \mathrm{wt} \% \mathrm{Cu}$ and $3.6 \mathrm{wt} \%$ content . Working conditions: voltage $20 \mathrm{kV}$; working distance: $6 \mathrm{~mm}$.

Figure 4. Relationship between the averaged percentages (\% wt) of $\mathrm{Zn}$ and $\mathrm{Cu}$ determined by means of EMP of the nucleus of a sub-set of the studied coins. Inset: percentages of Sn and $\mathrm{Zn}$. Data from [44].

Figure 5. Square wave voltammograms of samples a,b) 1 ( $A s$, Caesar, $45 \mathrm{BCE})$ and c,d) B15 (Sestertius, Tiberius, 22-23 CE) attached to graphite electrode in contact with air-saturated $0.25 \mathrm{M}$ $\mathrm{HAc} / \mathrm{NaAc}, \mathrm{pH}$ 4.75. Potential scan initiated at a,c) $+1.25 \mathrm{~V}$ in the negative direction; $\mathrm{b}, \mathrm{d})-1.25 \mathrm{~V}$ in the positive direction; potential step increment $4 \mathrm{mV}$; square wave amplitude $25 \mathrm{mV}$; frequency 5 $\mathrm{Hz}$.

Figure 6. Plots of: $i(\mathrm{~A} 1)$ vs. $i(\mathrm{C} 1)$ (squares) and b) $i(\mathrm{~A} 2)$ vs. $i(\mathrm{C} 1)$ (solid squares) for samples in this study. From square wave voltammograms in the conditions such as those in Figure 4.

Figure 7. Plots of $i(\mathrm{~A} 2)$ vs. $i(\mathrm{~A} 1)$ for: a) samples A9, 5, and 10; b) samples A9 and B5. Data points for five independent replicate measurements on each coin using square wave voltammograms such as in Figure 4b. Continuous lines correspond to the fit of experimental data points to a potential function.

Figure 8. Plots of $\ln (i(\mathrm{~A} 2))$ vs. $\ln (i(\mathrm{~A} 1))$ for Augustus' Sestertii grouped from the emission authority (coins A3 from Casius Celler, 213 and 228 from Gallius Lupercus, 234 from Gnaeus 
Calpurnius Piso, and 227 from Naevius Surdinus (solid squares), coins 235, 236 from Asinio Gallo (triangles) and coins 226, 232, 240 from Plotius Rufus (squares). From positive-going potential scan voltammograms such as in Figure $4 \mathrm{~b}$. Continuous lines correspond to the fit of experimental data points to a straight line. 
Figure 1.

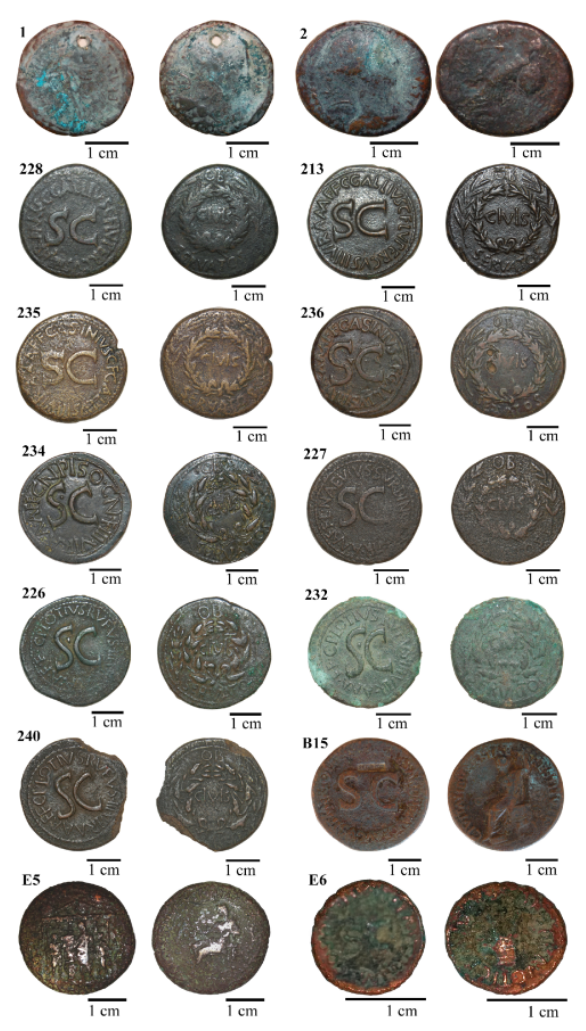


Figure 2.
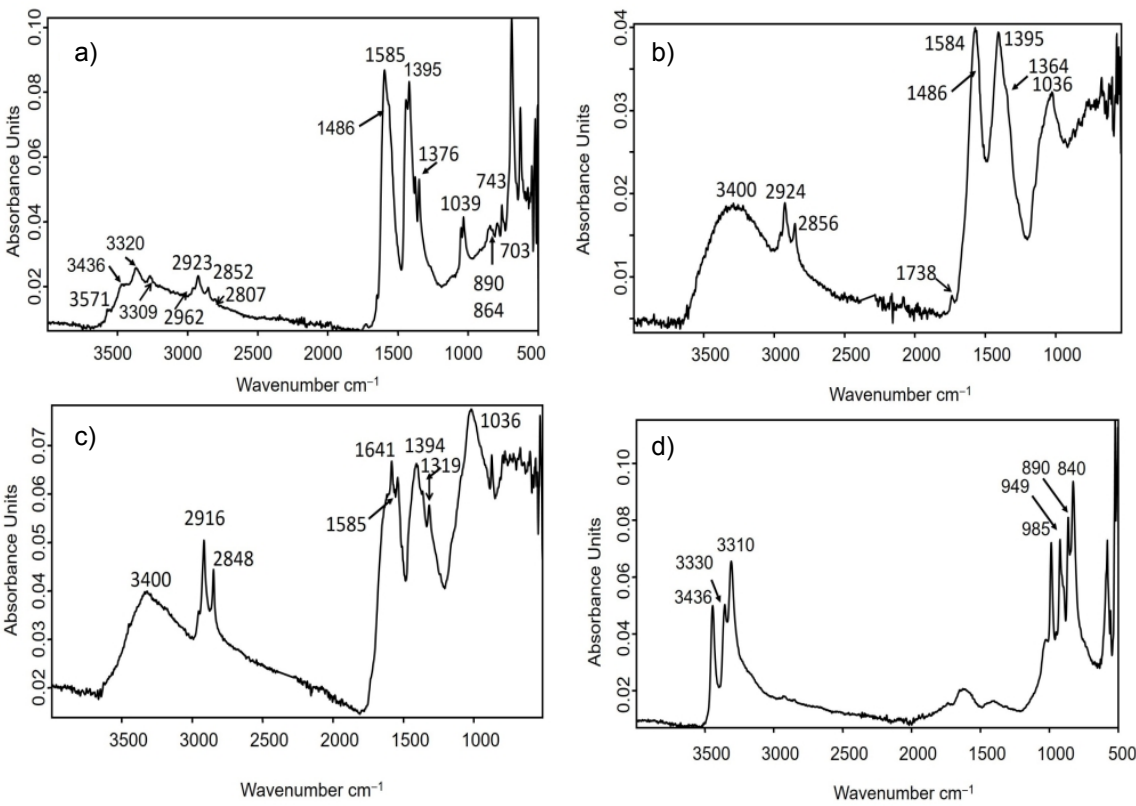
Figure 3.

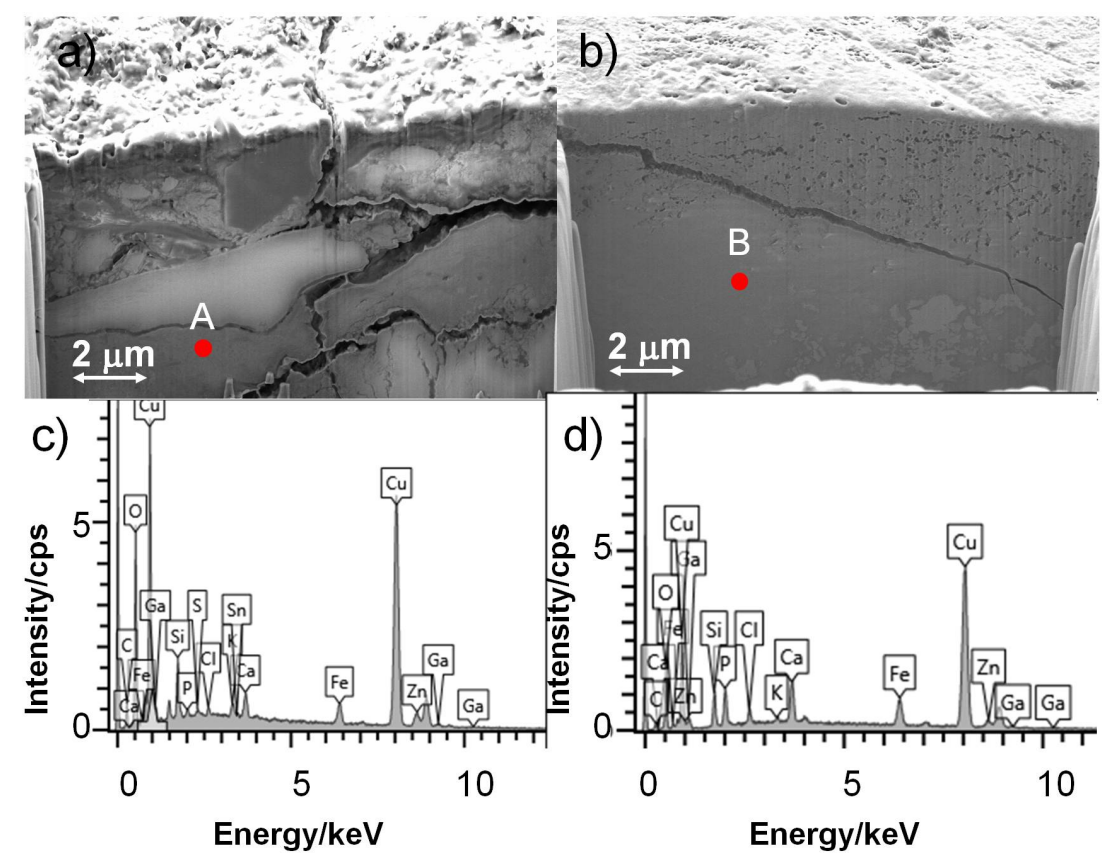


Figure 4.

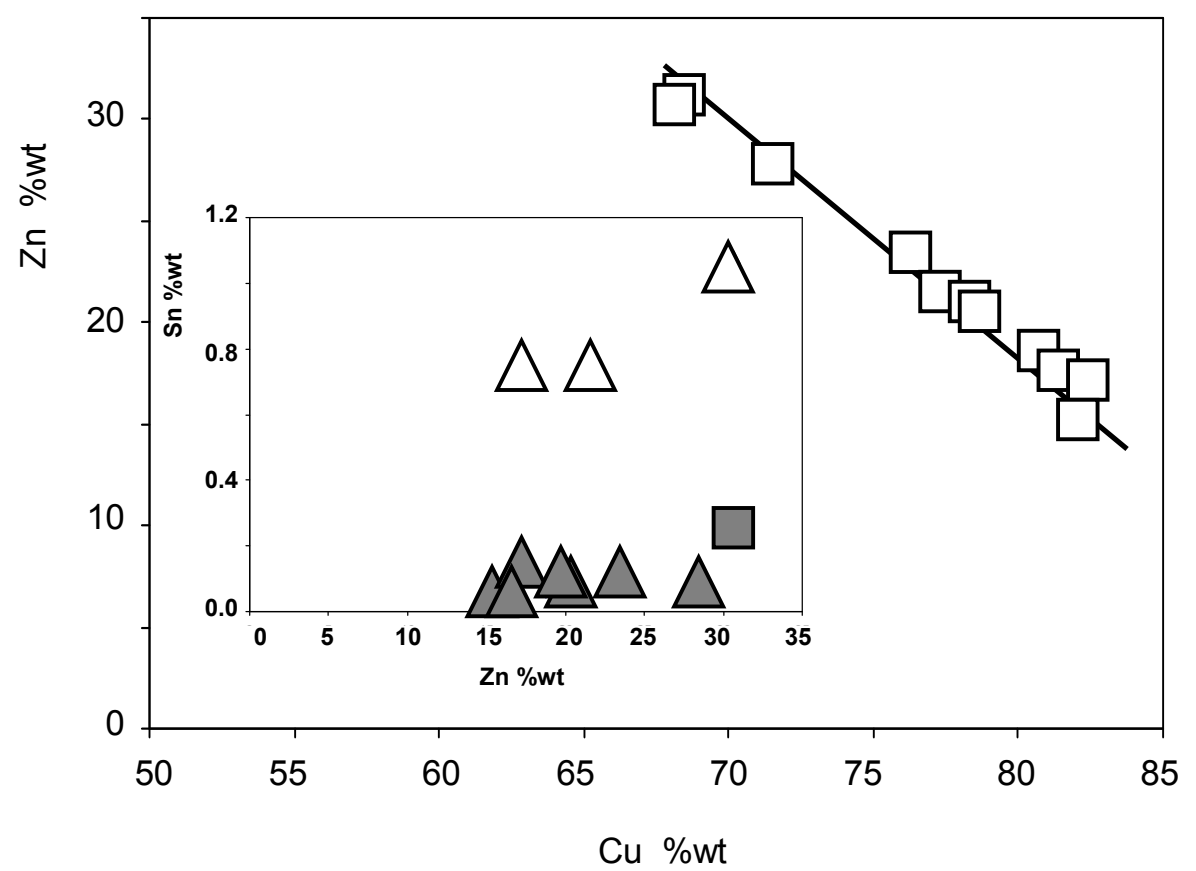


Figure 5.
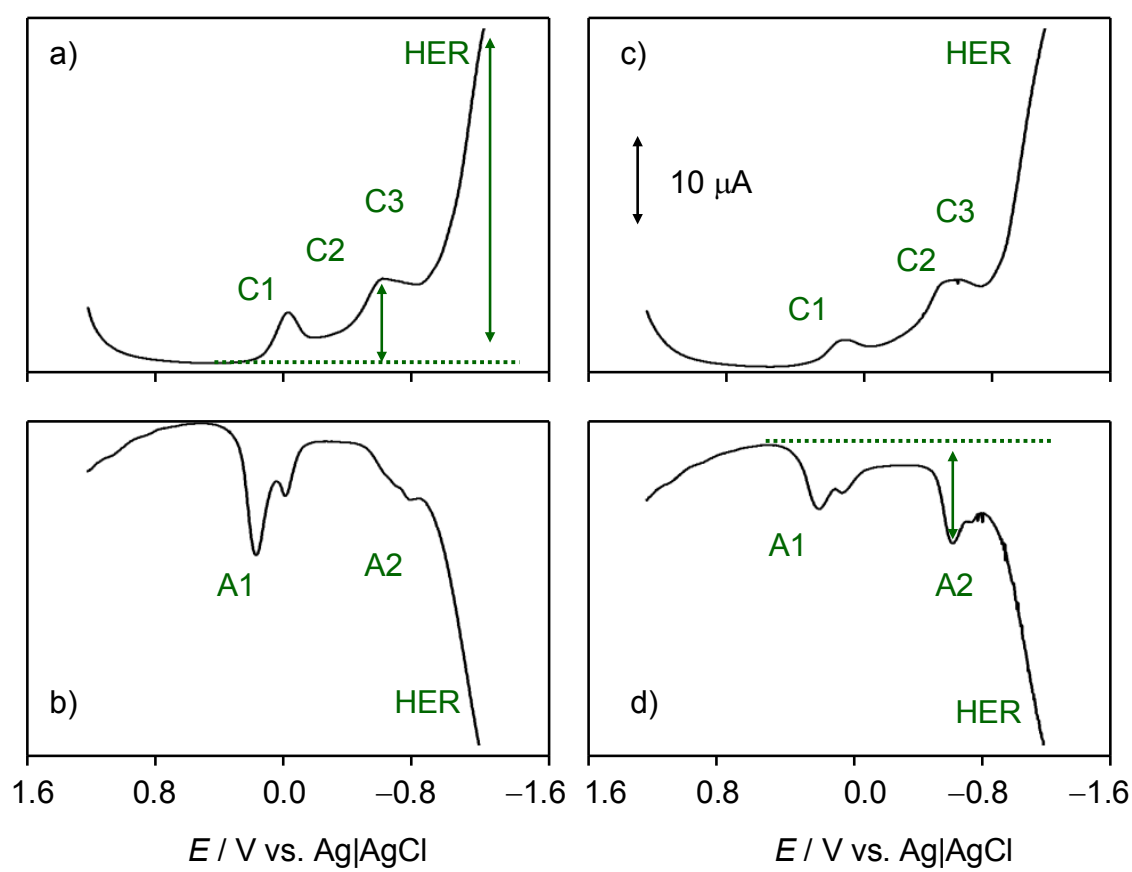
Figure 6.

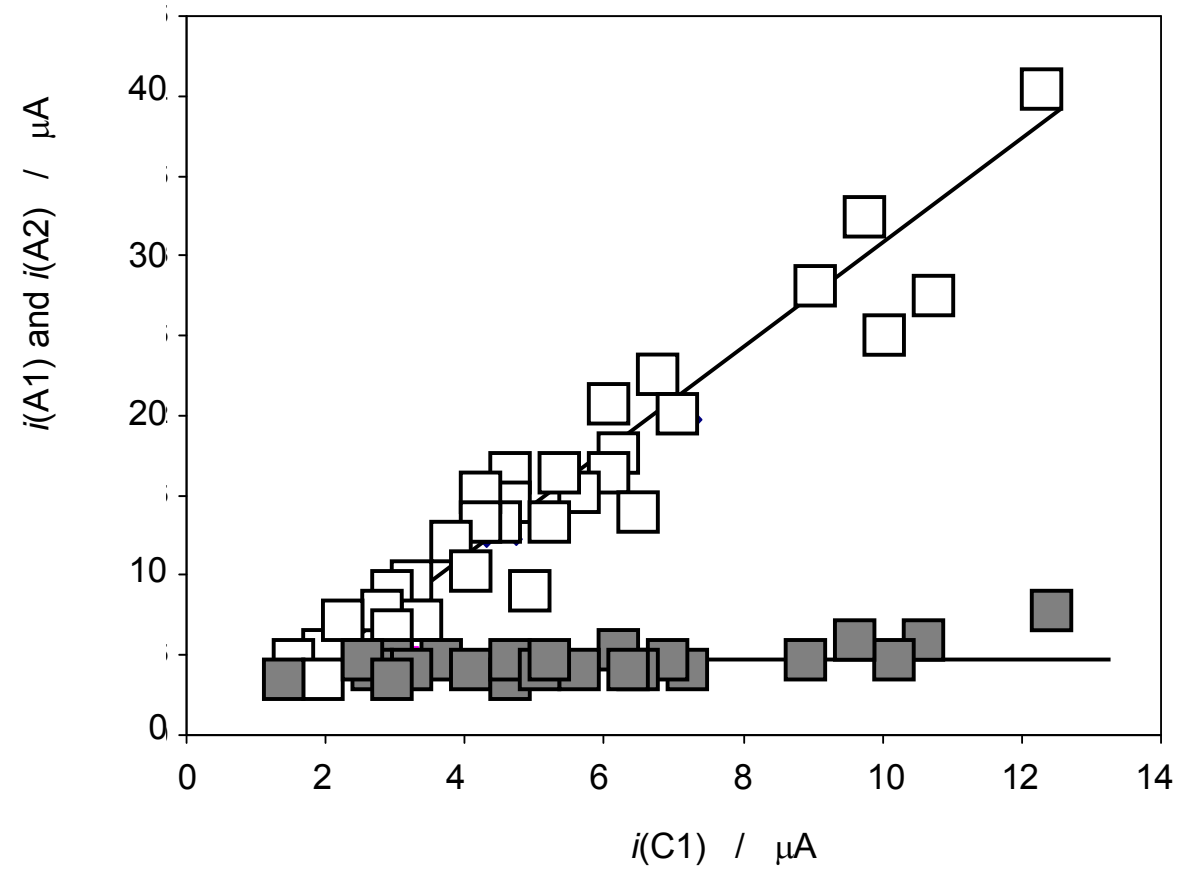


Figure 7.
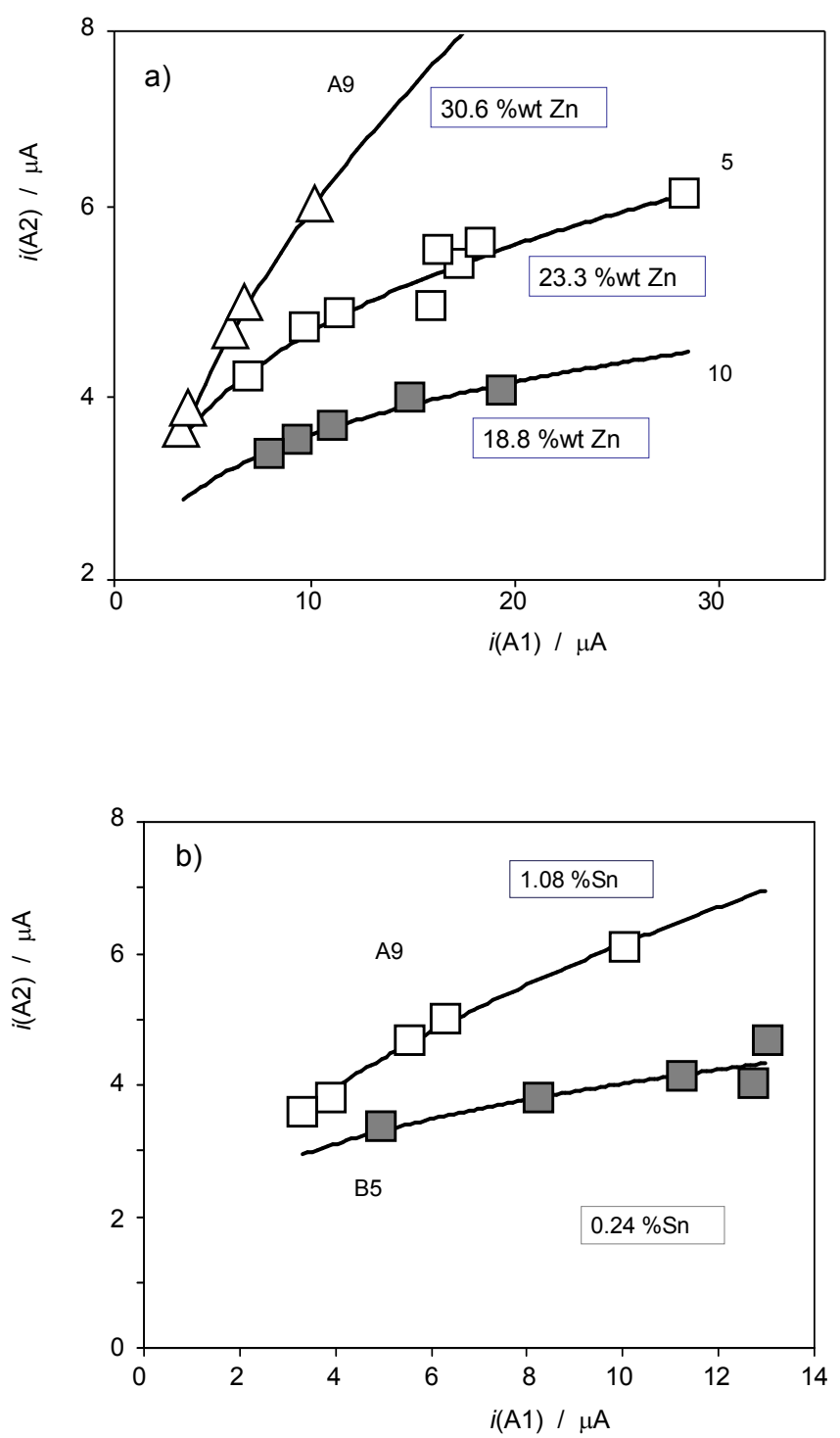
Figure 8.

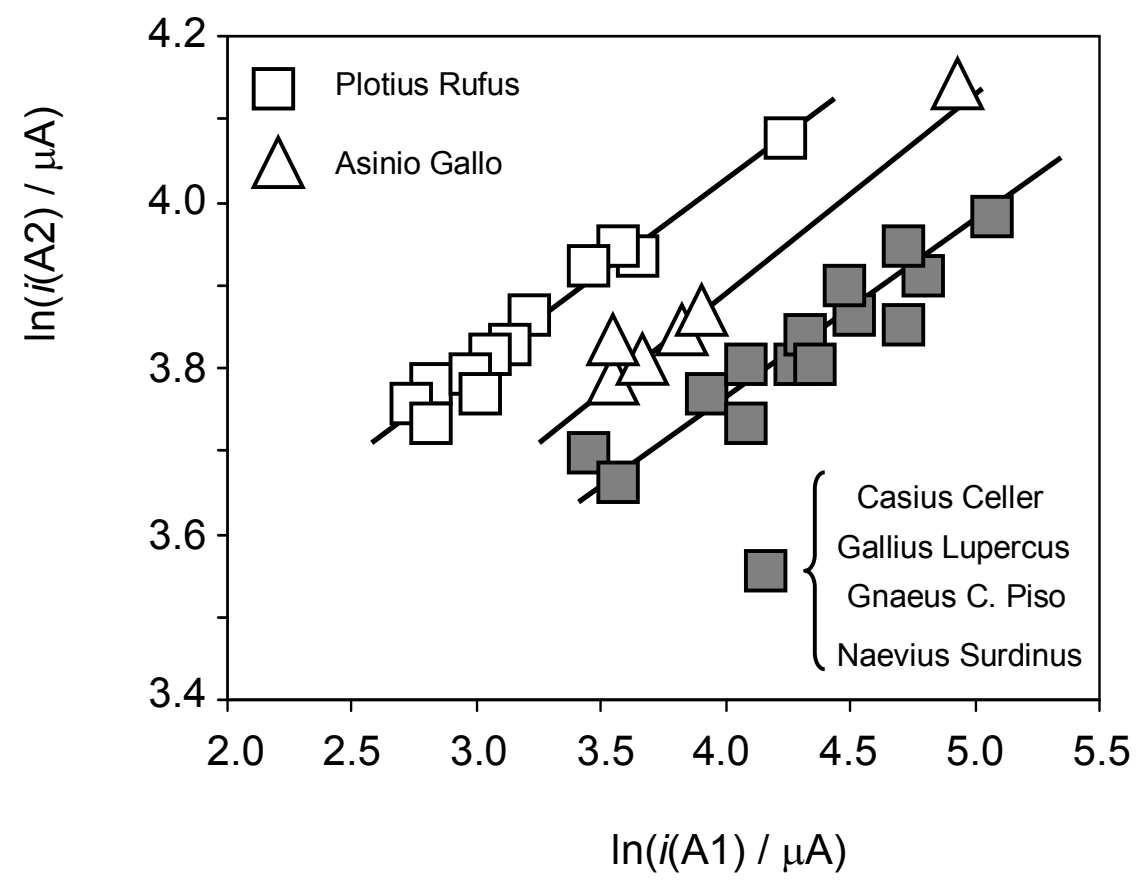


Table 1. Historic and numismatic information of the coin samples in this study. The conservation state is provided from visual test.

\begin{tabular}{|c|c|c|c|c|c|c|}
\hline Sample & $\begin{array}{l}\text { Denomination } \\
\text { (Authority) }\end{array}$ & Issuer & Year & Mint & Numismatic ref. & $\begin{array}{l}\text { Conservation } \\
\text { state }\end{array}$ \\
\hline A1 & As (-) & Q. Oppius & $88 \mathrm{BCE}$ & Laodicea & RRC 550/1-2 & Irregular patina \\
\hline A2 & $\begin{array}{l}\text { As (Julius } \\
\text { Caesar) }\end{array}$ & C. Clovius & $45 \mathrm{BCE}$ & Uncertain & RRC 476/1-2 & Irregular patina \\
\hline 1 & $\begin{array}{l}\text { As (Julius } \\
\text { Caesar) }\end{array}$ & - & $45 \mathrm{BCE}$ & - & - & Local Pitting corros. \\
\hline 2 & $\begin{array}{l}\text { As (Julius } \\
\text { Caesar) }\end{array}$ & - & $45 \mathrm{BCE}$ & - & - & Local Pitting corros. \\
\hline A3 & $\begin{array}{l}\text { Dupondius } \\
\text { (Augustus) }\end{array}$ & C. Cassius Celer & $16 \mathrm{BCE}$ & Rome & RIC I Augustus 375 & Irregular patina \\
\hline 228 & $\begin{array}{l}\text { Sestertius } \\
\text { (Augustus) }\end{array}$ & C. Gallius Lupercus & $16 \mathrm{BCE}$ & Rome & RIC I Augustus 377 & Good \\
\hline 213 & $\begin{array}{l}\text { Sestertius } \\
\text { (Augustus) }\end{array}$ & C. Gallius Lupercus & $16 \mathrm{BCE}$ & Rome & RIC I Augustus 377 & Good \\
\hline 235 & $\begin{array}{l}\text { Sestertius } \\
\text { (Augustus) }\end{array}$ & G. Asinio Gallo & $16 \mathrm{BCE}$ & Rome & RIC I Augustus 370 & Good \\
\hline 236 & $\begin{array}{l}\text { Sestertius } \\
\text { (Augustus) }\end{array}$ & G. Asinio Gallo & $16 \mathrm{BCE}$ & Rome & RIC I Augustus 370 & Good \\
\hline 234 & $\begin{array}{l}\text { Sestertius } \\
\text { (Augustus) }\end{array}$ & $\begin{array}{l}\text { Gnaeus Calpurnius } \\
\text { Piso }\end{array}$ & $15 \mathrm{BCE}$ & Rome & RIC I Augustus 380 & Good \\
\hline 227 & $\begin{array}{l}\text { Sestertius } \\
\text { (Augustus) }\end{array}$ & L. Naevius Surdinus & $15 \mathrm{BCE}$ & Rome & RIC I Augustus 383 & Good \\
\hline 226 & $\begin{array}{l}\text { Sestertius } \\
\text { (Augustus) }\end{array}$ & C. Plotius Rufus & $15 \mathrm{BCE}$ & Rome & RIC I Augustus 387 & Local Pitting corros. \\
\hline 232 & $\begin{array}{l}\text { Sestertius } \\
\text { (Augustus) }\end{array}$ & C. Plotius Rufus & $15 \mathrm{BCE}$ & Rome & RIC I Augustus 387 & Local Pitting corros. \\
\hline 240 & $\begin{array}{l}\text { Sestertius } \\
\text { (Augustus) }\end{array}$ & C. Plotius Rufus & $15 \mathrm{BCE}$ & Rome & RIC I Augustus 387 & Good \\
\hline 5 & $\begin{array}{l}\text { Sestertius } \\
\text { (Tiberius) }\end{array}$ & - & $\begin{array}{l}22-23 \\
\mathrm{CE}\end{array}$ & Rome & RIC I Tiberius 42 & Irregular patina \\
\hline E5 & $\begin{array}{l}\text { Sestertius } \\
\text { (Tiberius) }\end{array}$ & - & - & - & - & Good \\
\hline B15 & Sestertius & - & $22-23$ & Rome & RIC I Tiberius 48 & Local Pitting corros. \\
\hline
\end{tabular}




\begin{tabular}{|c|c|c|c|c|c|c|}
\hline & (Tiberius) & & $\mathrm{CE}$ & & & \\
\hline B4 & $\begin{array}{l}\text { Dupondius } \\
\text { (Caligula) }\end{array}$ & - & $\begin{array}{l}37-41 \\
\mathrm{CE}\end{array}$ & Rome & $\begin{array}{l}\text { RIC I Gaius/Caligula } \\
56\end{array}$ & Local Pitting corros. \\
\hline C9 & As (Caligula) & - & $\begin{array}{l}37-38 \\
C E\end{array}$ & Rome & $\begin{array}{l}\text { RIC I Gaius/Caligula } \\
35\end{array}$ & Irregular patina \\
\hline A9 & As (Claudius) & - & $\begin{array}{l}41-50 \\
\mathrm{CE}\end{array}$ & Rome & RIC I Claudius 100 & Irregular patina \\
\hline 10 & $\begin{array}{l}\text { Sestertius } \\
\text { (Claudius) }\end{array}$ & - & $\begin{array}{l}41-50 \\
\mathrm{CE}\end{array}$ & Rome & RIC I Claudius 99 (?) & Irregular patina \\
\hline B5 & $\begin{array}{l}\text { Sestertius } \\
\text { (Claudius) }\end{array}$ & - & $\begin{array}{l}50-54 \\
\mathrm{CE}\end{array}$ & Rome & RIC I Claudius 115 & Irregular patina \\
\hline E6 & $\begin{array}{l}\text { Quadrans } \\
\text { (Claudius) }\end{array}$ & - & - & - & - & Local Pitting corros \\
\hline B14 & Semis (Nero) & - & $\begin{array}{l}62-68 \\
\mathrm{CE}\end{array}$ & Rome & RIC I, 2 Nero 78 & Irregular patina \\
\hline 20 & $\begin{array}{l}\text { Sestertius } \\
\text { (Domitianus) }\end{array}$ & - & - & - & - & Local Pitting corros. \\
\hline
\end{tabular}


Table 2. Averaged composition of the metallic nucleus of a sub-set of the studied coins determined by EMP analysis. From ref. [44].

\begin{tabular}{|l|l|l|r|r|r|r|}
\hline Sample & Authority & Year & & & & \\
\hline & & & \%Cu & \%Zn & \%Sn & \%Fe \\
\hline A1 & Republica & 88 BCE & 77,12 & 21,3 & 0,73 & 0,32 \\
\hline A2 & Cesar & 45 BCE & 71,54 & 28,03 & 0,06 & 0,24 \\
\hline A3 & Augustus & 16 CE & 81,52 & 17,32 & 0,72 & 0,34 \\
\hline $\mathbf{5}$ & Tiberius & $22-23$ CE & 77,72 & 21,98 & 0,09 & 0,13 \\
\hline B4 & Caligula & $37-41$ CE & 82,37 & 17,32 & 0,13 & 0,07 \\
\hline $\mathbf{1 0}$ & Claudius & $41-50$ CE & 80,74 & 18,78 & 0,06 & 0,21 \\
\hline A9 & Claudius & $40-50$ CE & 68,19 & 30,64 & 1,08 & 0,01 \\
\hline A & Claudius & 50 CE & 78,83 & 20,64 & 0,07 & 0,34 \\
\hline B5 & Claudius & $50-54$ CE & 67,92 & 20,40 & 0,19 & 0,25 \\
\hline B14 & Nero & $54-68$ CE & 78,67 & 20,92 & 0,04 & 0,24 \\
\hline $\mathbf{2 0}$ & Domitianus & $81-96$ CE & 82,32 & 15,25 & 2,05 & 0,28 \\
\hline
\end{tabular}


The authors declare not existing conflicts of interest. 


\section{Supplementary Information}

Figure S.1. Square wave voltammograms (three replicate experiments sampling on three different spots of each coin) for samples from coin A9 ( $A s$, Claudius, 10-54 AD) in contact with air-saturated 0.25 M HAc/ $\mathrm{NaAc}, \mathrm{pH} 4.75$ Potential scan initiated at a-c) $+1.25 \mathrm{~V}$ in the negative direction; $\mathrm{d}-\mathrm{f}$ ) $-1.25 \mathrm{~V}$ in the positive direction; potential step increment $4 \mathrm{mV}$; square wave amplitude $25 \mathrm{mV}$; frequency of $5 \mathrm{~Hz}$.
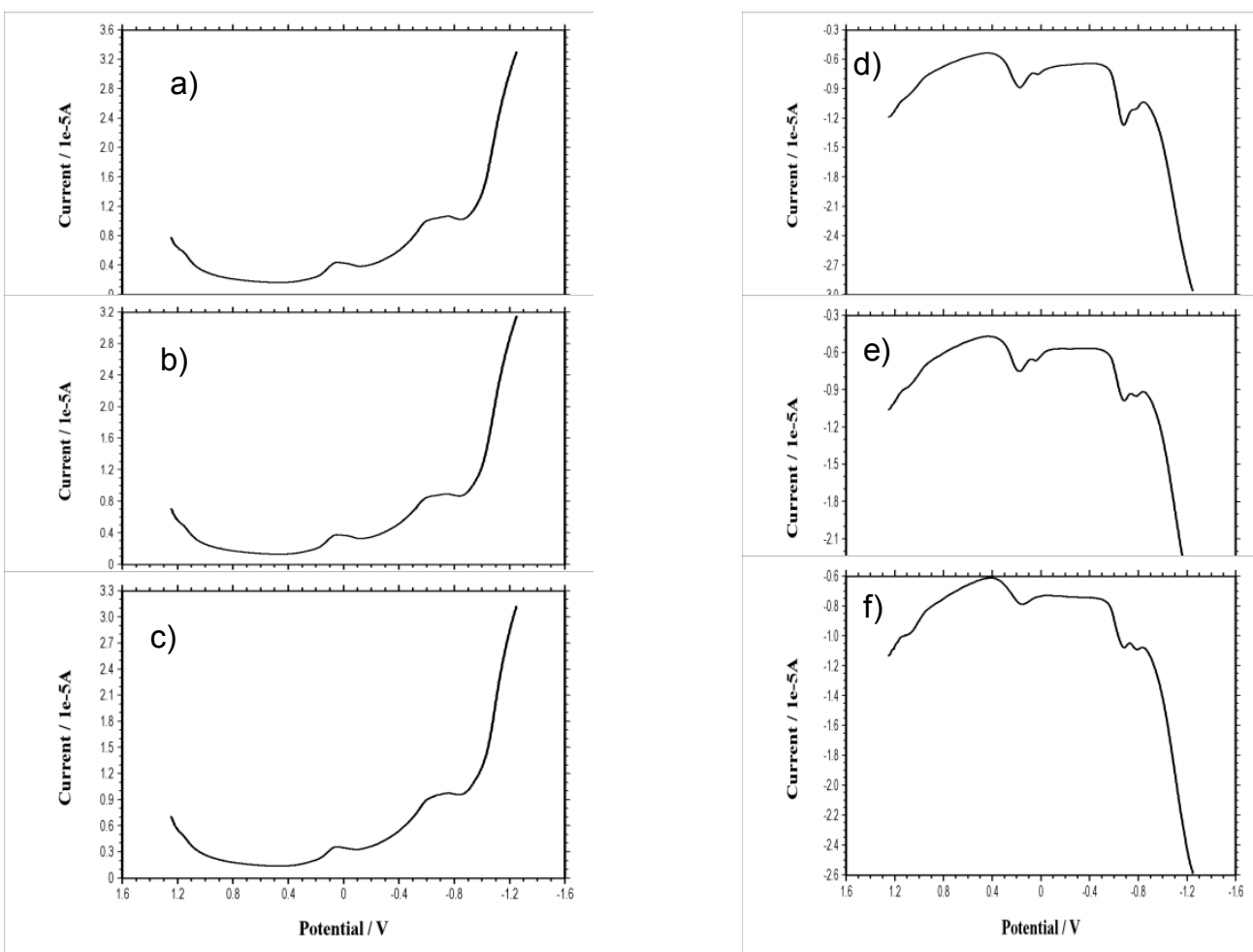
Figure S.2. Square wave voltammograms (three replicate experiments sampling on three different spots of each coin) for samples from coin 213 (Sestercius, Augustus, 16 $\mathrm{BC}$ ) in contact with air-saturated 0.25 M HAc/NaAc, $\mathrm{pH} 4.75$ Potential scan initiated at $\mathrm{a}-\mathrm{c})+1.25 \mathrm{~V}$ in the negative direction; $\mathrm{d}-\mathrm{f})-1.25 \mathrm{~V}$ in the positive direction; potential step increment $4 \mathrm{mV}$; square wave amplitude $25 \mathrm{mV}$; frequency of $5 \mathrm{~Hz}$.
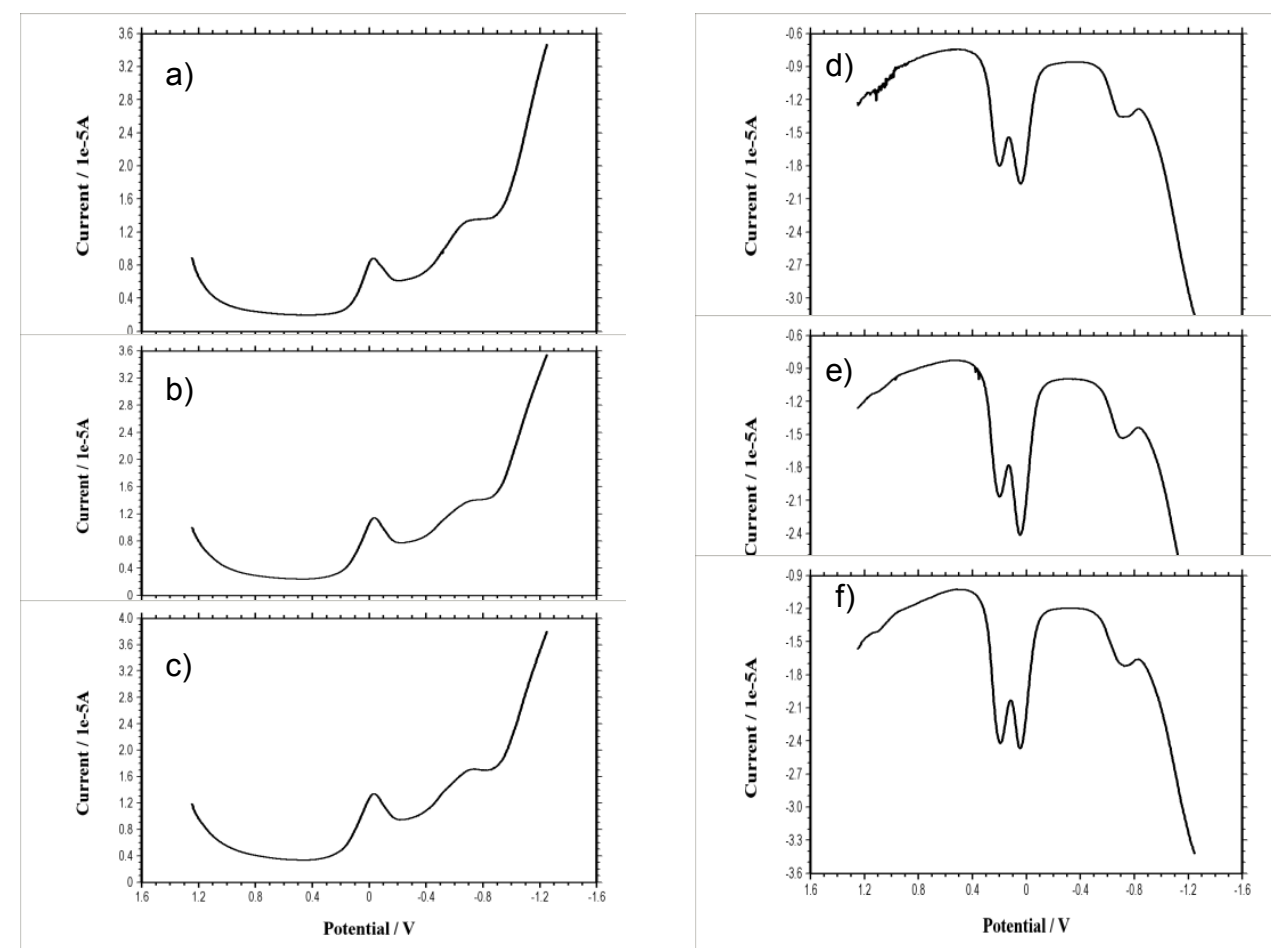